\title{
Non-Linguistic Challenges Faced by Malaysian Students in Enhancing Speaking Skills
}

\author{
N. Kala Nadesan1, Parilah Md. Shah² \\ ${ }^{1}$ Sekolah Menengah Kebangsaan Ayer Keroh, Melaka, Malaysia \\ ${ }^{2}$ Faculty of Education, Universiti Kebangsaan Malaysia, Bangi, Malaysia \\ Email: nkalamangai@gmail.com
}

How to cite this paper: Nadesan, N. K., \& Shah, P. Md. (2020). Non-Linguistic Challenges Faced by Malaysian Students in Enhancing Speaking Skills. Creative Education, 11, 1988-2001.

https://doi.org/10.4236/ce.2020.1110145

Received: September 6, 2020

Accepted: October 19, 2020

Published: October 22, 2020

Copyright (C) 2020 by author(s) and Scientific Research Publishing Inc. This work is licensed under the Creative Commons Attribution International License (CC BY 4.0).

http://creativecommons.org/licenses/by/4.0/

cc (i) Open Access

\begin{abstract}
One important skill that second language learners find difficult to acquire is speaking skills. Despite learning English language in both primary and secondary school, students face challenges to speak the language confidently. The purpose of this study was to in investigate the non-linguistic challenges faced by Malaysian students in enhancing speaking skills. This quantitative study used a questionnaire consisting 20 items based on five Likert scales. The purposive sampling of form three students, and data were collected from $13 \mathrm{fe}-$ males and 17 males. The data were analysed through SPSS software that suggest most students experience speaking skill is difficult, anxiousness, lack of confidence, shyness and afraid of making mistakes while speaking. The findings could help teachers to understand students' non-linguistics challenges in speaking skills and adapt various techniques to encourage students to speak in English language. It is suggested more studies need to be done to address speaking competency of students in Malaysian schools.
\end{abstract}

\section{Keywords}

Non-Linguistic Challenges, Speaking Skills, ESL

\section{Introduction}

Incompetence in speaking skill has been a major issue of concern since Malaysian students face challenges to acquire good proficiency. In Malaysian context, the classroom is where the communication takes place largely. Unfortunately, students are passive when comes to use the language for spoken interaction. Harmer (2001) explains that speaking involves communication of individuals. The speaker is required to comprehend what is being spoken and respond with the correct use of vocabulary. Bygate (1987) identified two important elements which 
are knowledge of the language and the skill. In order to produce successful communication, a speaker should be able to apply grammatical rules contextually. Thus, linguistic elements found in the language should be consolidated in the teaching learning process to enhance speaking skills of students.

Second language learners find it difficult to acquire speaking skills. Majority of secondary school students are unable to converse confidently during speaking activities. Students need to communicate to their peers or teacher during speaking activity. Harmer (2007) defines human communication as a complex process. When little communication takes place, interaction between students is insufficient to improve students' speaking skill. According to Richards \& Renandya (2002), speaking is used for a variety of purposes that involves many skills thus, the capability to speak a new language is challenging for second language learners. Banu (2017) identified that students do not have enough encouragement to practice the language to speak outside the classroom. According to Gill (2013), the language policies by the government did not yield any significant results as the standard of English was declining. Hence, teaching and learning activities in the classroom has a great impact on the language proficiency of learners. Adapting various speaking activities in the class provides good space and opportunity to interact and tap learners' creativity alongside using the target language. Musa et al. (2012) stated that after 11 years of learning English, students are still unable to exhibit proficiency in English language. Thus, students' performance should be consolidated in the secondary school so that they are cognitively mature to contribute to the society and nation. The secondary school is a critical phase that prepares students to pursue higher education at tertiary level or enter the workforce where communicative competence is emphasized as an important element. The present proficiency level in English is worryingly low. The Cambridge Baseline Study conducted in 2013 to identify the proficiency levels of students revealed that the performance level was below the expected proficiency level. The weakest of the four skills was speaking skills among students and teachers (Malaysian Education Blueprint 2013-2025). Kaur (2006) pointed out that English lessons in Malaysia only focused on reading and writing essays and little time was allocated for listening and speaking skills to enhance English language proficiency. Besides, Baker \& Westrup (2006) argued that teachers worldwide focus only on grammar and vocabulary that are being tested in examinations. Thus, speaking is a neglected language skill. Though, students may possess sound knowledge of rules and rich vocabulary because they sail through the assessment, but they face challenges to converse in English beyond the classroom. The Malaysian Ministry of Education has implemented effective measures that address the challenges in speaking. One of the strategies implemented by the Ministry of Education was the implementation of School Based Assessment (SBA) in the lower secondary school to reduce exam-oriented culture by emphasizing on effective teaching in the classroom. The set system was introduced in 2012 to categorize pupils according to bands based on the learning ability to cater to individual 
learners' needs. In addition, it aimed to encourage pupils to learn according to one's learning style. Besides that, Oral Proficiency Programme was introduced in selected schools to encourage pupils to communicate in the second language. In addition, the implementation of the Peningkatan Pengajaran Bahasa Inggeris Sekolah was introduced to the low performing schools to raise the English language proficiency of secondary school students via a specialized school support plan (Don et al., 2015). Malaysian students generally need more practice since communication happens more spontaneously in real life Speaking skill is often neglected in language program by language teachers despite the fact that the lack of focus in the said skill causes anxiety and lack of confidence in language learners (Bada, Genc, \& Ozkan, 2011).

Florez (1999) claims speaking as two-way interaction that involves producing and processing information. Previous studies suggest that the students are aware of the importance of the English language, but unable to see the immediate need to practice English as a medium of interaction, especially when talking with others who speak the same first language. This view indirectly influenced the students rather negatively towards learning the English language. In short, the students do not have the immediate need to learn the language since it is possible to survive in the community without a good command of soft skills. Hence, providing the necessity to know, appreciate, and practice English language is crucial to tap the students' motivation and desire to learn this language. The call to align the Malaysian English Language Curriculum to the CEFR requires all four skills to be assessed and in school based and national assessment. Speaking is one of the main four language skills (speaking, reading, listening, and writing).

The purpose of the study is to investigate the non-linguistic challenges faced by secondary school students during speaking activities in the English language lessons. It is also to suggest ways to overcome the non-linguistic challenges of speaking skill in the classroom. Therefore, the research questions that guide this study are:

1) What are the non-linguistic speaking challenges faced by lower secondary students?

2) Is there a significant difference between males and females with respect to non-linguistic speaking challenges?

\section{Literature Review}

\subsection{Elements of Speaking Competency}

\section{Elements of Speaking Competency}

Developing one's language competency is complex because one has to understand the knowledge to process the information received. According to Harmer (2001), a speaker should possess knowledge of language features to register information immediately and to understand the aim of interaction. Meanwhile, Bygate (1987) distinguishes facilitation and compensation as two devices that is involve in production of speaking skills On the other hand, Bachman \& Palmer 
(1996) distinguishes language competence as textual competence, when the speaker is able to join utterances to form a meaningful structure besides applying the knowledge based on words according to grammatical aspect that govern a language. Speaking competency is to use the language structure to converse according to context. Besides that, an element relating to the abovementioned factor is grammatical competence; which refers to situation when the learner is able to speak with the correct use of mechanics of language accurately. Schiffrin (2006) defines a learner should not only possess the repertoire of the language but also the use of cohesive devices to exchange ideas and take turn in discussions. Speaking competency also involves sociolinguistic competence; which is the ability to use the form and function of the language based on the situational and societal needs. Strategic competence, which refers to the learners' ability to process information with the correct structure of the language both verbally and non -verbally, contributes to speaking competency too.

\subsection{Challenges Students Face in Speaking Skills}

\section{Non-Linguistic Challenges}

The performance of the students depends on the time limit and guidance given. According to Oxford (1990), one important aspect that contributes to language learning is the affective side of students. Similarly, Krashen (1981) claims that affective elements are related to second language learning and the variables are motivation, self-confidence and anxiety that affects students speaking performance. Non-linguistic challenges that students face in speaking skills could be categorized into internal and external.

\section{1) Internal Barriers}

According to Pratolo et al. (2019), second language learners' speaking skill is influenced by three factors. Firstly, the knowledge of the language that governs the language. If students do not know the use of accurate vocabulary, they are unable to participate in a discussion. Secondly, the use of mother tongue while speaking, where the grammatical rules differ from one language to another. Therefore, it hinders the speaking competency in the second language. Thirdly, the peer pressure that a student experience during speaking activities compared to other students who has good command of speaking skills. In addition, parents' encouragement to speak the language outside the school or institution could also enhance students' speaking proficiency. Thirdly, the teaching and learning environment that inspires students' learning, where every student is given equal opportunity to speak. According to Riasati (2014), in the research EFL learners' opinions on aspects affecting one's desire to communicate in English language lesson, classroom climate influence students' speaking interaction and performance. Bachman \& Palmer (1996), further emphasized that to be a competent communicatively, one should be able to use the mental ability to process components of language to interact accordingly. However, when communication occurs, non-linguistic elements becomes a challenge to second language learners. This can hamper a second language learner's speaking skill. Spoken interaction 
in a second language is influenced by linguistic and non-linguistic elements that hamper a learner to speak confidently. Some non-linguistic challenges impede a second language learner's speaking skill such as anxiety, shyness, lack of interest, fear of being wrong, low participation and lack of motivation.

Anxiety is caused when a student is uncomfortable to speak a foreign language in front of many people. Wrench et al. (2009) are in view that students cannot learn when they experience apprehension that results in poor performance in speaking skill. Similarly, they exhibit the same attitude in the classroom setting when they experience such emotion. Spada \& Lightbrown (1993) believe that speaking depends on the situation where the speaker needs to deliver to a crowd of audience but sometimes anxiety becomes an obstacle in a learning environment that affect speaking activities.

Students of less motivated classes opt to use mother tongue during speaking task as it comes naturally and easier to be expressed. Thornbury (2007) further explains that a sound proficiency in the language does not ensure a good spoken competency since fluency of the targeted language is affected by mother tongue-use. Students prefer to be quiet or silent in the classroom due to low selfesteem which is caused by to incompetency in speaking a foreign language. $\mathrm{Nu}$ nan (1999) states students who are not confident of themselves and their proficiency in the language suffer poor communicative competence. He \& Chen (2010) state the key aspect of students' low confidence is their low capability of speaking in English.

Baldwin (2011) affirms that one common fear that second language learners experience when they speak in a second language in front of many people could make them feel shy. This aspect could impede and affect their speaking performance because feeling of shyness could make them forget what to say and become totally blank. Abdalla \& Elhadi (2015) observed that some learners are naturally shy by birth and that is a challenge for them to speak in the language. Saurik in Tambunan et al. (2018), identifies that most of English students are reluctant to speak the target language fearing the mistakes that they make while speaking.

Ur (2000) stated that learners often experience inhibition while attempting to converse in a new language in the classroom. Besides, they fear they will be mocked and the teacher may develop a negative impression. Aftat (2008) adds that this fear is related to correction and the embarrassment of being mocked. Therefore, students stop speaking afraid being ridiculed by the teacher. Gardner \& Smythe (1982) believes that a learner's effort towards learning influence the outcome of the results. According to Littlewood \& William (1981), learners should be motivated to express views to enhance speaking skills. Motivation is vital in acquiring a second language because it encourages one to participate in an oral task. Littlewood \& William (1981) suggests that creating a conducive learning environment is one aspect that facilitate learning a language. Thornbury (2007) concludes that each speaking task should be effective and productive 
for autonomous use.

According to Tuan \& May (2015), low participation could be another challenge because not everyone will be able to speak for long time. In such situation, one student will be given only a short time to speak, while other students may dominate the discussion. Khan \& Khan (2016) explained that a real-life communication should be facilitated, along with learners' background knowledge should be kept in mind, and the background knowledge to be chosen so that the learning process becomes an interesting journey.

\section{2) External Barriers}

One aspect that contributes to speaking skill is exposure to listening skill in second language to facilitate comprehending information. Hamouda (2013) claims that when students understand information received besides learning new vocabulary. On the other hand, enhancing proficiency in listening skill is vital to upgrade proficiency in speaking, and listening is the main mode by which receiving ideas and information is internalized. Therefore, listening skill has a significant role in developing speaking skills.

Topic selection is an important tool in the language classroom to motivate students to speak. Hamouda (2013) agrees that students will initiate to speak when the topic interests them. They don't have ideas when they cannot relate it to their background knowledge. However, they also become quiet and do not participate when the topic is uninteresting.

\subsection{Teacher's Role in the Speaking Classroom}

Bygate (2009) states that speaking is not an easy part of language learning, it is a different kind of engagement with the foreign language and hence requires different types of learning activities. A good planning in guidance in speaking activities that teachers need to practice in the speaking classroom is essential.

Goh et al. (2012) suggest a number of strategies in relation to what teachers should focus on in planning and guiding speaking activities. The strategies include engaging in a variety of basic skills, focusing on meaning, using grammar flexibly, using accurate vocabulary, employing linguistic needs according to context, using effective discourse methods and inculcating metacognitive awareness of speaking second language in learners.

In addition, according to Horwitz et al. (1986), teachers can help students to cope with the existing anxiety by providing a conducive learning environment. On the other hand, Harmer (1991) explains that if teachers corrects students' mistakes, it will affect the spoken interaction and defeat the objectives. This view is supported by Baker \& Westrup (2003) who mentioned that correcting students' mistakes will eventually demotivate and obstruct participation. They suggest positive comments to help students to speak. Hence, teachers can encourage students to speak by following a number of effective strategies. According to Anuradha et al. (2014), teachers could motivate students from the very first lesson, be patient for students' repetitive mistakes, accept one word response to 
question asked, allow students to make mistakes while communicating in English language, prompt phrases to and the language use in various contexts, carry out tasks that engage in speaking and avoid correcting errors in the initial stage of speaking.

The communicative language teaching aims to provide real life situation for students to interact with each other in the target language. Engaging students to participate collaboratively would enhance the speaking skills in a classroom environment. To realize the objective and to make students to speak fluently, teachers could adapt various techniques to lower students' anxiety levels

Harmer (1988) believes that the teacher has great potential to facilitate speaking skill by providing a balanced moral support to speak the language confidently. Besides, teachers can become a prompter by providing some ideas so that students can progress with the discussion or think critically. This could motivate students' interest and learning spirit in a positive environment.

Harmer (1988) adds that giving feedback in speaking activities is crucial so that students are able to understand their strengths and weaknesses. However, teachers have to be cautious not to overcorrect the mistakes which will hinder their communication. On the other hand, a positive evaluation can encourage the students to do better in future speaking activities. The success of carrying out a speaking task relies on the teacher's instruction that is clear and concise so there is no misconceptions among students. Besides, students could also be asked to evaluate their own work and give suggestions to improvise. The development of speaking skill requires a variety of fun filled activities that create more chances for students to speak. Moreover, according to Cutrone (2009), there are some ways that teachers can help reduce language anxiety in the classroom. First of all, they can employ activity types that could cause lower levels of anxiety such as pair work and then gradually introduce activity types that could cause higher levels of anxiety such as giving speeches. In addition, teachers can help students to better cope with anxiety-provoking issues themselves by guiding on implementing language learning strategies, writing a journal and interpersonal skills.

Bygate (1987) concludes that teachers should employ facilitation and compensation strategies to assist learners' oral production. The essential aspect of teaching speaking skills lies in creating ample opportunity to practice the language to communicate. To conclude, teachers should vary their teaching approaches that are conducive for developing students' speaking skills. Teachers easily can identify students speaking issues in the classroom and should take some effective measures to help the students to carry out speaking tasks under different conditions.

Acquiring speaking skill in a second language is not easy as the students need to be comfortable as they have to adapt various ways like attempting to pronounce and utter words like native speakers. Romero et al. (2009) believes that second language learners can overcome issues related to speaking by mastering both the rules and sounds. This explains that mastery in oral performance can be 
improved. Therefore, the teachers' role is vital to facilitate students' speaking production. Teachers need to understand students' needs and overcome the challenges students face with suggestion and application of solution.

According to Nunan (1999), teachers should observe five principles of teaching speaking in the classroom; namely, teachers need to remember to distinguish difference between second language learning and foreign language context, provide opportunity to practice fluency and accuracy while carrying out speaking task, assign group or pair work to interact, ensure the speaking has element of negotiation and design tasks that are well guided in practice as well as transactional and interaction.

Baker \& Westrup (2003) provided guidelines for teachers, stating that teachers could create maximum opportunity by creating a conducive climate that has collaborate task work, use of original material, involve every student's participation, reduce teacher's speaking and observe students, give positive and building comments, prompt to guide speaking and introduce English as a medium of conversation. Besides teachers' role in the speaking classroom, students have to take autonomy of one's learning too. This is in line with what Oktavia (2014) suggested; that students could use simple and easy language to speak with their friends. Besides, they could also try to speak in group discussions since this would pave way to reduce inhibition. On the other hand, using every opportunity to converse in English with classmates and friends will also positively affect speaking skills.

\section{Methodology}

\subsection{Population and Sample}

The study was conducted with form three students of SMK Ayer Keroh, Melaka. The age of the respondents in this population is fifteen. From the total of 235 students a sample of 30 students were selected. For the sample of this research, simple random sampling was done across the seven form Three classes to determine the respondents of the study. Thirty students were selected to be the respondents of the study. Creswell (2012) defines, convenience sampling eases the researcher because this type of sampling is convenient, whereby the researcher can reach the participants easily, especially if they are accessible. Therefore, the researcher chose these participants because they are available for the research. Convenience and purposeful sampling were used. This research is crucial for these participants since the form three students will be assessed in the public examination to address the issues related to speaking.

\subsection{Instrument: Questionnaire}

According to Creswell (2004), a web-based questionnaire is a survey instrument for collecting data that is available on computer. Murgan (2015) defined questionnaire as a set of questions to find out general views or characteristics about a situation or group of people. The questionnaire that was used for this research is 
divided into two parts. Part one comprises of demographic and background information such as gender of the respondents. Part 2 of the questionnaire consists of 20 questions relating to the challenges that students face in speaking skill. These questions have been adapted from Abdullah et al. (2019) who investigated non-linguistic elements that affect students speaking skill. Since this questionnaire was adapted from Abdullah et al. (2019), it has a consistency of 0.79 Cronbach's Alpha; which means that the items are reliable, and that the data collection was accurate.

\subsection{Data Collection Procedure}

The questionnaire was distributed via google form. Items in the questionnaire were designed on five-point Likert scale ranging from strongly disagree to strongly agree. The researcher created the items of the questionnaire based on the literature reviewed. Before distributing the questionnaire, the researcher obtained the approval from the school authorities to carry out the research to collect the data. Then, the researcher explained the questionnaire and described the aim of the research. The completion of the questionnaire took about 10 minutes.

\section{Findings}

\subsection{Non-linguistic Challenges that are Mostly Faced by Students}

\begin{tabular}{ccccccccccccccccccccccccccc}
\hline & & & & & & & & & & Q1 & Q1 & Q1 & Q1 & Q1 & Q1 & Q1 & & Q1 \\
\hline & Q1 & Q2 & Q3 & Q4 & Q5 & Q6 & Q7 & Q8 & Q9 & 0 & 1 & 2 & 3 & 4 & 5 & 6 & Q17 & Q18 & 9 & 0 \\
\hline Mea & 4.1 & 4.2 & 3.8 & 4.3 & 4.2 & 4.1 & 3.8 & 4.0 & 3.6 & 3.7 & 3.9 & 3.8 & 3.8 & 3.9 & 3.9 & 3.9 & & & 3.8 & 3.8 \\
$\mathrm{n}$ & 0 & 7 & 7 & 0 & 3 & 3 & 7 & 3 & 0 & 7 & 0 & 7 & 0 & 0 & 3 & 7 & 3.83 & 3.80 & 0 & 7 \\
$\mathrm{~N}$ & 30 & 30 & 30 & 30 & 30 & 30 & 30 & 30 & 30 & 30 & 30 & 30 & 30 & 30 & 30 & 30 & 30 & 30 & 30 & 30 \\
Std. & 0.99 & 0.82 & 0.73 & 0.79 & 0.72 & 0.90 & 0.93 & 0.89 & 0.85 & 0.85 & 0.88 & 0.81 & 0.80 & 0.88 & 0.90 & 0.99 & 1.02 & 1.03 & 0.92 & 0.81 \\
Dev & 5 & 8 & 0 & 4 & 8 & 0 & 7 & 0 & 5 & 8 & 5 & 9 & 5 & 5 & 7 & 9 & 0 & 1 & 5 & 9 \\
\hline
\end{tabular}

All the items have the mean scores between the ranges of three to four. The average level of non-linguistic challenges faced by the secondary school students was in the range of "Agree" to neutral. Items which gained higher mean scores in this dimension were identified as "I find speaking skill is difficult if there is a time limit" ( $\mathrm{M}=4.30, \mathrm{SD}=0.794)$, "I have no interest in speaking" $(\mathrm{M}=4.27$, $\mathrm{SD}=0.828)$, "I do not like to participate in group discussion and pair activities in English ( $\mathrm{M}=4.23, \mathrm{SD}=0.728)$, "I am reluctant to participate when classmates are more dominant in group discussion" $(\mathrm{M}=4.13 . \mathrm{SD}=0.928)$, "I find speaking skill difficult" ( $\mathrm{M}=4.10, \mathrm{SD}=0.995)$ and "I feel shy during a presentation in the class" $(\mathrm{M}=4.03, \mathrm{SD}=0.890$. Meanwhile, three items show similar mean score which are items 13,18 and $19(M=3.80)$. Besides this, items 7, 12 and 20 display same findings respectively $(M=3.87)$ "I can't speak when the whole class pay attention to me, "I am embarrassed when the teacher corrects my mistakes when I speak", "I feel shy to start a conversation in English "reflect students ex- 
perience shyness afraid of being wrong when they speak. Items 11 and 13 exhibit the same results $(M=3.90)$ which is about being laughed by friends for making mistakes while speaking. The results revealed that only a minority of students were neutral. The non-linguistic challenges that Malaysian secondary students face hamper the students speaking in the classroom. They are 1) Students find speaking is difficult in a limited time 2) Students have no interest to speak in English, 3) Students do not like to participate in group discussions and pair activities in English, 4) Students are reluctant to participate when other students dominate the discussion 5) students find speaking skill difficult 6) Students can't speak when the whole class pay attention 7) students feel embarrassed when the teacher corrects the mistakes while speaking, 8) Students can't start a conversation due to shyness.

\subsection{Differences in Challenges Faced by Male and Female Students}

\begin{tabular}{|c|c|c|c|c|c|c|c|c|}
\hline & & \multicolumn{7}{|c|}{ t-test for Equality of Means } \\
\hline & & \multirow{2}{*}{$\mathrm{t}$} & \multirow{2}{*}{$\mathrm{df}$} & \multirow{2}{*}{$\begin{array}{c}\text { Sig. } \\
\text { (2-tailed) }\end{array}$} & \multirow{2}{*}{$\begin{array}{c}\text { Mean } \\
\text { Difference }\end{array}$} & \multirow{2}{*}{$\begin{array}{l}\text { Std. Error } \\
\text { Difference }\end{array}$} & \multicolumn{2}{|c|}{$\begin{array}{l}\text { 95\% Confidence Interval of the } \\
\text { Difference }\end{array}$} \\
\hline & & & & & & & Male & Female \\
\hline \multirow{2}{*}{ Q1 } & Equal variances assumed & -2.191 & 28 & 0.037 & -0.750 & 0.342 & -1.451 & -0.049 \\
\hline & Equal variances not assumed & -2.268 & 24.516 & 0.032 & -0.750 & 0.331 & -1.432 & -0.068 \\
\hline \multirow{2}{*}{ Q2 } & Equal variances assumed & -1.473 & 28 & 0.152 & -0.438 & 0.297 & -1.046 & 0.171 \\
\hline & Equal variances not assumed & -1.508 & 26.810 & 0.143 & -0.438 & 0.290 & -1.033 & 0.158 \\
\hline \multirow{2}{*}{ Q3 } & Equal variances assumed & -2.688 & 28 & 0.012 & -0.652 & 0.243 & -1.149 & -0.155 \\
\hline & Equal variances not assumed & -2.730 & 27.780 & 0.011 & -0.652 & 0.239 & -1.141 & -0.163 \\
\hline
\end{tabular}

It could be concluded from that overall, the difference in challenges faced by male and female respondents of this study is not significant. The only items that have significant scores are item 1 and 3. Item 1 required students to state if they find speaking skills difficult and item 3 required respondents to state if they feel anxious to speak in front of many people.

\section{Discussion and Conclusion}

\subsection{Discussion}

The finding of the study revealed students find speaking as a difficult skill. The respondents face problems when the speaking activity is given in a limited time. According to Holland (2018), apprehension is caused when the students fear what is to come. Horwitz (1991) believes, students' oral production is affected when they experience such body response and the apprehension level is reduced when there is support given by the teacher during a speaking lesson. When students are in a comfortable environment, they can overcome speaking challenges. The teacher plays an important role as to guide and give clear instructions for students to speak in the target language. Teachers have to be very cautious when 
correcting students by not making negative remarks that affect students' motivation to show progress and interest to upgrade speaking proficiency. In addition, the speaking task should be planned carefully so that it attracts students' attention and they could rely on background knowledge to speak. As for speaking in pairs, it can be encouraging for the students to participate in a less threatened situation. On the other hand, students lack confidence and feel shy to participate fearing to be misjudged by the peers or teacher. Besides, they developed a negative attitude towards speaking skill in the target language. Moreover, feeling shy to speak in front of a crowd can cause them to feel demotivated to speak totally. Similarly, shy children naturally shy to speak are unable to speak confidently. In a study conducted by Crozier \& Hostettler (2003) revealed that shy children and adults are seemingly rather quiet during social interactions and it is not easy for them to start a conversation in the second language. However, Shamsa (2011) pointed out negative peer pressure could result in poor performance in speaking skill. This situation could discourage a learner to participate in a discussion or keep silent. As for research question two, the findings are in line with the statement by Ur (2000), who stated that speaking skill is the toughest skill to acquire and with Harmer (1988), who stated that second language learning can cause students to experience anxiousness. To conclude, the findings of the study suggest there is no significant non-linguistic challenges between males and females.

\subsection{Suggestions}

Future researchers could collect data from the secondary school teachers' knowledge of teaching tasks and the types of approaches being practiced identifying the real challenges that the students face during a speaking lesson. Besides, teachers themselves should have sound knowledge on how to assign the tasks while providing the accurate support needed by the learner. On the other hand, teacher should also focus on the speaking opportunities employed to conduct speaking lesson in CEFR class. Hence, it is important for teachers to facilitate the students in a non-threatening environment, so the students feel free to attempt to speak. It is suggested that code switching should be avoided in the teaching learning strategy so that students will attempt to speak in English language. Moreover, the speaking task should be a fun filled activity that would encourage students to participate actively. It is suggested that teachers should upgrade their teaching skills based on learner ability to understand the challenges clearly. Besides, a study could be conducted to identify speaking challenges faced by high proficient and low proficient learners' similarity and difference with regards to speaking skill.

\subsection{Implications}

The Malaysian secondary school students' non-linguistic challenges can be addressed by focusing on speaking skill. The internal barriers have influenced students speaking efficacy. To address the issues related to the non-linguistic chal- 
lenges faced by students, many factors need to be addressed. Teachers' selection should not be compromised when it comes to the selection of teachers who are competent particularly in speaking skill. The teachers should be given appropriate training as how to select, adapt and organize speaking activities for students that call for active participation. Besides, teacher should be guided on how to integrate activities cross the curriculum and co-curricular activities that calls for greater opportunities to speak and interact with peers and teachers. The exposure to speak the language could motivate students to speak in the language outside the classroom confidently. Furthermore, teacher should refrain from using the mother tongue as medium of interaction in the class. The school can organize inter class debate, role-play and public speaking competitions with attractive rewards to attract students to participate. Teachers should be given sufficient training on how to carry out the appropriate speaking tasks by the Ministry of Education and ensure teachers are selected for teachers' training based on a good command of speaking skill. In addition, teachers should be given intensive courses and hand on training to cater for large class to minimize the speaking challenges by creating a rich learning environment.

\section{Acknowledgements}

I would like to thank Dr Parilah M. Shah and Ms Marsha for their helpful comments on earlier drafts of this paper. Next, I would like to thank the participants for their contribution in the data collection process of this study.

\section{Conflicts of Interest}

The authors declare no conflicts of interest regarding the publication of this paper.

\section{References}

Abdalla, M. E., \& Elhadi, E. N. (2015). Problems of Teaching and Learning Spoken English in Sudan.

Abdullah, M. Y., Hussin, S., \& Ismail, K. (2019). Implementation of Flipped Classroom Model and Its Effectiveness on English Speaking Performance. International Journal of Emerging Technologies in Learning, 14, 130-147. https://doi.org/10.3991/ijet.v14i09.10348

Aftat, M. (2008). Motivation and Genuine Learning.

Anuradha, R. V., Raman, G., \& Hemamalini, H. C. (2014). Methods of Teaching English. Hyderabad: Neelkamal Publications.

Bachman, L., \& Palmer, A. S. (1996). Language Testing in Practice. Oxford: Oxford University Press.

Bada, E., Genc, B., \& Ozkan, Y. (2011). Speak the Real: News Articles as Major Source for Oral Competence. In English as a Second Language (pp. 121-134). New York: Nova Science Publishers Inc.

Baker, J., \& Westrup, H. (2003). Essential Speaking Skill. London: Continuum.

Baker, J., \& Westrup, H. (2006). Essential Speaking Skill (2nd ed.). London: Continuum.

Baldwin, C. (2011). How to Overcome Shyness during an Oral Presentation. 
http://www.ehow.com/how-overcome-shyness-during-oral-presentation.html

Banu, R. (2017). Difficulties Faced by College Student in Speaking English-A Sociological Reflection. International Journal of Trend in Research and Development, 4, 435.

Bygate, M. (1987). Speaking. Oxford: Oxford University Press.

Creswell, J. W. (2012). Educational Research: Planning, Conducting, and Evaluating Quantitative and Qualitative Research (4th Edition). London: Pearson.

Crozier, W. R., \& Hostettler, K. (2003). The Influence of Shyness on Children's Test Performance. British Journal of Educational Psychology, 73, 317-328. https://doi.org/10.1348/000709903322275858

Cutrone, P. (2009). Overcoming Japanese EFL Learners' Fear of Speaking. Language Studies Working Papers, 1, 55-63.

Don, Z. M., Abdullah, M. H., Abdullah, A. C., Lee, B. H., Kaur, K., Pillai, J., \& Hooi, M. Y. (2015). English Language Education Reform in Malaysia: The Roadmap 2015-2025. Putrajaya: Ministry of Education Frantzen.

Florez, M. A. C. (1999). Improving Adult English Language Learners' Speaking Skills.

Gardner, R. C., \& Smythe, P. C. (1982). The Role of the Integrative Motive on Students' Participation in the French Classroom. Canadian Modern Language Review, 38, 625647. https://doi.org/10.3138/cmlr.38.4.625

Gill, R. S. (2013). Enhancing English Teacher Language Proficiency: The Malaysian Experience. https://www.britishcouncil.or.th/sites/default/files/dr.ranjit.pdf

Goh, C. C. M., Goh, C., \& Burns, A. (2012). Teaching Speaking. Ernst KlettSprachen.

Hamouda, A. (2013). An Exploration of Causes of Saudi Students' Reluctance to Participate in the English Language Classroom. International Journal of English Language Education, 1, 17-34. https://doi.org/10.5296/ijele.v1i1.2652

Harmer (2001). The Practice of English Language Teaching. London: Longman. https://doi.org/10.1177/003368820103200109

Harmer, J. (1988). Teach English. London: Longman.

Harmer, J. (1991). The Practice of English Language Teaching. Essex: Longman.

Harmer, J. (2007). How to Teach English: New Edition. Harlow: Pearson Education Limited. https://doi.org/10.1093/elt/ccn029

He, S. X., \& Chen, A. J. Y. (2010). How to Improve Spoken English. https://sites.google.com/site/languagejournal/home/how-to-improve-spoken-English

Horwitz, E. K., Horwitz, M. B., \& Cope, J. (1986). Foreign Language Classroom Anxiety. The Modern Language Journal, 70, 125-132. https://doi.org/10.1111/j.1540-4781.1986.tb05256.x

Kaur, N. (2006). Non-Autonomy and Low-English Proficiency among Malaysian Students: Insights from Multiple Perspectives. In K. Ariffin, M. R. Ismail, N. K. Leng, \& R. A. Aziz (Eds.), English in the Malaysian Context (pp. 21-34). Shah Alam: University Publication Centre (UPENA) UiTM.

Khan, T. J., \& Khan, N. (2016). Obstacles in Learning English as a Second Language among Intermediate Students of Districts Mianwali and Bhakkar, Pakistan. Open Journal of Social Sciences, 4, 154-162. https://doi.org/10.4236/jss.2016.42021

Krashen, S. (1981). Second Language Acquisition and Second Language Learning. New York: Pergamon.

Littlewood, W., \& William, L. (1981). Communicative Language Teaching: An Introduction. Cambridge: Cambridge University Press.

Murgan, M. G. (2015). A Critical Analysis of the Techniques for Data Gathering in Legal 
Research. Journal of Social Sciences and Humanities, 1, 266-274.

Musa, N. C., Lie, K. Y., \& Azman, H. (2012). Exploring English Language Learning and Teaching in Malaysia. GEMA Online ${ }^{\circledast}$ Journal of Language Studies, 12.

Nunan, D. (1989). Designing Tasks for the Communicative Classroom. Cambridge: Cambridge University Press.

Nunan, D. (1999). Designing Task for the Communicative Classroom. Cambridge: CUP.

Oktavia, S. (2014). Students' Anxiety in Speaking EFL in One of Senior High School in Kota Jambi.

Oxford, R. L. (1990). Language Learning Strategies: What Every Teacher Should Know. New York: Newbury House Publishers.

Pratolo, B. W., Habibie, A. F., \& Setiawan, A. (2019). Speaking Skills Challenges Encountered by Indonesian EFL Learners. Advances in Social Science, Education and Humanities Research, Vol. 370, 160-164. https://doi.org/10.2991/adics-elssh-19.2019.7

Riasati, M. J. (2014). Causes of Reticence: Engendering Willingness to Speak in Language Classrooms. International Journal of Research Studies in Language Learning, 3, 115-122. https://doi.org/10.5861/ijrsll.2013.410

Richards, J. C., \& Renandya, W. A. (2002). Methodology in Language Teaching: An Anthology of Current Practice. Cambridge: Cambridge University Press. https://doi.org/10.1017/CBO9780511667190

Romero, D. M., Tinjacá Bernal, L. M., \& Carrero Olivares, M. (2009). Using Songs to Encourage Sixth Graders to Develop English Speaking Skills. Profile Issues in Teachers Professional Development, 14, 11-28.

Schiffrin, D. (2006). From Linguistic Reference to Social Reality. Studies in Interactional Sociolinguistics, 23, 103. https://doi.org/10.1017/CBO9780511584459.006

Shamsa Aziz, D., Akhtar, Z., \& Hassan, H. (2011). A Study of Peer and Parent Pressure on Pakistani Youth: Gender Wise Comparison. International Journal of Academic Research, 3.

Spada, N., \& Lightbrown, P. (1993). Instruction and the Development of Questions in L2 Classrooms. Studies in Second Language Acquisition, 15, 205-224.

https://doi.org/10.1017/S0272263100011967

Tambunan, A. R. S., Saragih, W., Pane, I. I. I., \& Siregar, T. M. (2018). Adversities and Challenges on Listening and Speaking Learning of the English Language Students. Journal of English Language Studies, 3, 31-40. https://doi.org/10.30870/jels.v3i1.2848

Thornbury, S. (2007). How to Teach Speaking. London: Pearson Education Limited.

Tuan, N. H., \& Mai, T. N. (2015). Factors Affecting Students' Speaking Performance at LE Thanh Hien High School. Asian Journal of Educational Research, 3, 8-23.

Ur, P. (2000). A Course in Language Teaching: Practice and Theory. Cambridge: Cambridge University Press.

Wrench, J. S., Goding, A., Johnson, D. I., \&Attias, B. A. (2009). Stand Up, Speak Out: The Practice and Ethics of Public Speaking. 